\title{
Tekanan Psikologis Mahasiswa Saat Pembelajaran Jarak Jauh Selama Pandemi COVID-19
}

\author{
Titik Kristiyani \\ Fakultas Psikologi Universitas Sanata Dharma \\ Paingan Maguwoharjo Depok Sleman Yogyakarta \\ Email: titikpsy@usd.ac.id
}

\begin{abstract}
Abstrak
Penelitian ini bertujuan untuk menggambarkan kondisi tekanan psikologis, faktor-faktor yang mempengaruhi, serta dinamika tekanan psikologis mahasiswa dalam pembelajaran jarak jauh saat pandemi COVID-19. Responden penelitian ini adalah 548 mahasiswa dari berbagai universitas di Yogyakarta. Desain penelitian yang digunakan adalah desain analisis isi kualitatif. Data dikumpulkan dengan menggunakan kuesioner terbuka. Temuan dalam penelitian ini meliputi: (1) mahasiswa mengalami tekanan psikologis dalam bentuk kecemasan, kepanikan, merasa terbebani, bosan, kesepian, tidak percaya diri, hingga berdampak pada menurunnya motivasi belajar; (2) tekanan psikologis mahasiswa dalam pembelajaran jarak jauh dipengaruhi oleh faktor input mahasiswa dan dosen, lingkungan belajar, kebutuhan bersosialisasi, fasilitas belajar jarak jauh, serta dukungan finansial; (3) dinamika tekanan psikologis yang dialami mahasiswa dapat dijelaskan sebagai berikut: faktor yang mempengaruhi tekanan psikologis secara langsung adalah ketidakyakinan pada kemampuan diri yang disebabkan karena ketidakjelasan pengelolaan belajar beserta evaluasinya. Ketidakjelasan tersebut muncul karena kombinasi faktor kompetensi dan etos kerja dosen, kompetensi akademik dan softskill mahasiswa, serta kurang memadainya fasilitas pembelajaran jarak jauh.
\end{abstract}

Kata kunci: pembelajaran jarak jauh, tekanan psikologis, pandemi COVID-19, pengelolaan pembelajaran

\begin{abstract}
Title: Psychological Pressure of Students While Distance Learning During the COVID-19 Pandemic

This study aims to describe psychological stress, factors affecting psychological stress, and the dynamic of psychological stress of undergraduate students in long-distance learning during pandemic COVID-19. Respondents of this study are 548 undergraduate students from many universities in Yogyakarta. This study uses a qualitative design with qualitative content analysis. The open-ended questionnaire is used to gain the data. Results of this study are : (1) psychological stress experienced by undergraduate students are anxiety, panic, feeling overwhelmed, bored, lonely, not confidence and have an impact on decreasing motivation to learn; (2) undergraduate students psychological stress is affected by some factors, namely students and lecturer input, learning atmosphere, socialization need, facilities of long-distance learning, and financial support; (3) the dynamics of psychological stress can be explained as follows: the factor that directly affects psychological stress is the low of self-efficacy that is triggered by learning delivery and learning evaluation disorganized. This condition arises due to a combination of competency factors and lecturers' work ethic, academic competence, and student soft skills, as well as inadequate distance learning facilities.
\end{abstract}

Keywords: long distance learning, psychological stress, pandemic COVID-19, learning organization. 


\section{Pendahuluan}

Perubahan mendadak telah terjadi dalam dunia pendidikan di semua jenjang pendidikan selama pandemi COVID-19 ini. Di perguruan tinggi, pertemuan tatap muka di kelas harus berubah secara tiba-tiba menjadi perkuliahan non tatap muka atau online, tanpa persiapan yang memadai, baik dari dosen maupun mahasiswa. Perubahan tersebut terjadi dalam rangka melaksanakan himbauan sosial atau physical distancing untuk mencegah penularan COVID-19.

Pembelajaran non tatap muka memiliki ragam istilah, seperti online learning, elearning, atau pembelajaran jarak jauh. Semuanya memiliki kesamaan dalam hal terpisahnya pembelajar dan pengajar secara fisik. Istilah online learning didefinisikan sebagai model pembelajaran yang meletakkan tempat sebagian atau sepenuhnya melalui penyampaian informasi melalui internet. Dengan kata lain, pengetahuan disediakan pada pengguna tanpa batasan waktu dan letak geografis (Aparicio, Bacao dan Oliveira, 2016). E-learning merupakan penyampaian pelatihan atau pendidikan dengan menggunakan berbagai media elektronik, khususnya internet (Ellis, Jarkey, Mahony, Peat dan Sheely, 2007). Pembelajaran jarak jauh dirumuskan sebagai model pengajaran dan teknologi yang bertujuan memberikan pengajaran kepada pembelajar yang secara fisik tidak dapat hadir dalam kondisi belajar konvensional, misalnya dalam ruang kelas (Bušelić, 2012). Dari tiga istilah itu, dapat dilihat kesamaan intinya, yaitu pada tidak terdapatnya interaksi secara langsung melalui tatap muka fisik serta digunakannya media dalam proses pembelajaran. Demi konsistensi istilah, dalam penelitian ini akan digunakan istilah pembelajaran jarak jauh, yang selanjutnya disingkat PJJ.

Sebenarnya, model PJJ tidak dapat dikatakan sebagai sesuatu yang baru. Wacana tentang PJJ sudah sejak lama muncul sebagai tanggapan atas perkembangan teknologi komunikasi dan informasi. Dengan model PJJ, banyak hal dapat dilakukan secara online. Ketika internet mulai akrab dengan masyarakat, pembelajaran berbasis internet pun mulai banyak dikembangkan, dengan tujuan mengatasi kendala ruang dan waktu demi memperluas khalayak pembelajar.

Perkembangan terus berlanjut hingga muncul banyak model pembelajaran di abad 21. Sekitar tahun 2014 ketika teori disrupsi mulai berkembang, dunia pendidikan seakan dibuat panik dengan munculnya prediksi menjamurnya pendidikan digital yang berpotensi 'menghantam' eksistensi pembelajaran konvensional. Inilah periode yang memicu munculnya banyak teknologi model pembelajaran. Selain untuk menjawab tantangan disrupsi, model-model pembelajaran ini juga dipikirkan sebagai upaya mengimbangi generasi pembelajar milenial yang highly mobile dan sering dianggap sebagai self-learner. Pemerintah juga telah mencanangkan paradigma pendidikan abad 21 sebagai persiapan memasuki Revolusi Industri 4.0, dengan pilar 4C, yaitu critical thinking, communication, collaboration, and creative.

Keterangan tersebut cukup menggambarkan bagaimana model PJJ yang harus dijalani saat ini. Sebenarnya sudah ada dalam kerangka berpikir dunia pendidikan Indonesia, sehingga asumsinya mental setting sudah terbangun. Tetapi, pada kenyataannya, tak dapat dipungkiri terasa 'gagap'nya masyarakat pendidikan ketika 
disrupsi ini benar-benar terjadi dan tidak dapat dielakkan lagi. Keluhan terkait pelaksanaan PJJ pun banyak diungkapkan, baik oleh mahasiswa maupun dosen. Contoh keluhan-keluhan yang muncul misalnya banyaknya tugas yang diberikan dengan batas waktu pengumpulan yang sempit, minimnya penjelasan materi oleh dosen dan kurang responsifnya dosen. Keluhan-keluhan yang muncul tersebut merupakan tanda bahwa mahasiswa maupun dosen mengalami tekanan psikologis tertentu selama proses PJJ ini.

Jika dilihat dalam kerangka tujuan mencetak pembelajar mandiri, maka yang dilakukan para pengajar dengan pemberian tugas, baik berupa membaca mandiri maupun latihan pengerjaan soal, kiranya sangat mendukung terbentuknya kebiasaan belajar berdasar regulasi diri, yang berdampak pada tercapainya pembelajaran yang efektif. Menurut Bjork, Dunlosky dan Kornell (2013), pembelajaran yang efektif tidak hanya dilihat dari kemampuan mengukur hasil belajar secara akurat, tetapi juga dilihat dari kemampuan mengelola pembelajaran dan kegiatan-kegiatan untuk memantaunya. Prediktor keberhasilan akademik juga terletak pada kemampuan mengelola proses belajar itu sendiri (Macejka, 2014). Filosofi PJJ kiranya juga persis mensyaratkan dimilikinya kemandirian belajar sekaligus mendukung terbentuknya kemampuan mengelola belajar secara mandiri.

Dari paparan tersebut, tampak adanya suatu masalah, di mana kendati kemandirian belajar merupakan hal yang penting dalam pembelajaran, tetapi rupanya para pembelajar belum sepenuhnya memiliki kemampuan tersebut. Inilah yang menjadi salah satu pemicu munculnya tekanan psikologis yang dialami mahasiswa, di mana mahasiswa merasa dipaksa belajar mandiri dalam kondisi penuh kekhawatiran akibat pandemi COVID-19.

Menyadari kenyataan tersebut, maka kondisi tekanan psikologis yang dialami para mahasiswa akibat pembelajaran jarak jauh, kiranya menjadi kenyataan yang perlu dihadapi dan dipahami faktor-faktor pemicu serta dinamika psikologinya. Apalagi PJJ ini terjadi di tengah pandemi, yang mungkin tanpa persiapan pengelolaan sistem pembelajaran dan pengelolaan diri sendiri yang matang.

Tekanan psikologis yang dialami pembelajar terbukti mempengaruhi kemampuan belajar dan prestasi akademik menjadi rendah (Pascoe, Hetrick dan Parker, 2020; Zembylas, Theodorou dan Pavlakis, 2008). Tekanan psikologis biasa disebut dengan istilah stres, yaitu kondisi emosi seseorang yang terjadi ketika tuntutan eksternal muncul melebihi kemampuan penyesuaian diri orang tersebut (Lazarus dan Folkman, 1984). Stres yang dialami pembelajar akan berpengaruh pada kepuasan dalam belajar, yakni persepsi subjektif tentang seberapa baik lingkungan belajar mendukung prestasi akademik. Kepuasan yang tinggi terhadap proses belajar akan memicu kemampuan berpikir dan belajar secara optimal (Lo, 2010).

Selain berpengaruh langsung terhadap prestasi akademik, tekanan psikologis juga berdampak pada kualitas hidup dan kesejahteraan psikologis (Ribeiro et al., 2017). Tekanan hidup juga dapat memicu munculnya gangguan kesehatan mental, gangguan tidur dan penggunaan obat terlarang (Pascoe, Hetrick dan Parker, 2020). Kesejahteraan psikologis merupakan pusat eksistensi manusia, termasuk mahasiswa. Para mahasiswa merupakan calon-calon pemimpin masa depan. Bagi 
mereka, keberhasilan akademik merupakan capaian hidup yang berharga dan dianggap sebagai tujuan yang penting dalam hidup. Untuk mencapai tujuan tersebut, penting bagi mahasiswa untuk senantiasa memiliki kondisi kesehatan psikologis yang baik. Atmosfer penuh tekanan dapat memicu stres dan menurunkan performansi belajar (Dwyer dan Cummings, 2001).

Dengan banyaknya dampak tekanan psikologis bagi pembelajar, yang tidak hanya di area akademik tetapi juga dalam aspek kehidupan lainnya, maka penting kiranya mengetahui lebih lanjut mengenai tekanan psikologis mahasiswa beserta faktorfaktor pencetusnya, guna melakukan antisipasi agar tekanan psikologis di kalangan mahasiswa dapat diminimalisir.

Berdasarkan latar belakang tersebut, maka pertanyaan yang diajukan dalam penelitian ini adalah:

1. Bagaimana tekanan psikologis yang dialami mahasiswa saat belajar jarak jauh selama pandemi COVID-19?

2. Apa saja faktor-faktor yang mempengaruhi tekanan psikologis mahasiswa saat belajar jarak jauh selama pandemi COVID-19?

3. Bagaimana dinamika tekanan psikologis mahasiswa saat belajar jarak jauh selama pandemi COVID-19?

\section{Metode}

Penelitian ini merupakan jenis penelitian kualitatif dengan desain analisis isi kualitatif. Responden dalam penelitian ini adalah 548 mahasiswa dari beberapa universitas di Yogyakarta. Responden terdiri dari 295 (53,8\%) laki-laki dan 253 $(46,2 \%)$ perempuan. Pencarian responden dilakukan dengan kriteria mahasiswa aktif di Yogyakarta, yang masih mengambil mata kuliah (bukan mahasiswa yang sedang mengerjakan tugas akhir). Responden terdiri dari mahasiswa jurusan eksakta kesehatan, eksakta non kesehatan, serta sosial humaniora, dari Perguruan Tinggi Negeri (PTN) dan Perguruan Tinggi Swasta (PTS) yang ada di Yogyakarta.

Data penelitian dikumpulkan dengan menggunakan kuesioner terbuka, yang disebarkan melalui Google Form pada akhir April hingga awal Mei 2020. Kuesioner terbuka yang diisi responden merupakan kuesioner untuk mengetahui situasi mahasiswa selama pandemi COVID-19 yang terdiri dari kecemasan terhadap situasi pandemi, kecenderungan mengikuti perkembangan fenomena COVID-19, perilaku pencegahan penularan COVID-19, hal-hal terkait pembelajaran jarak jauh, harapan saat ini, serta gagasan pencegahan penularan COVID-19 sesuai bidang ilmu masing-masing. Khusus untuk mengetahui kondisi psikologis responden yang dilaporkan dalam naskah ini, pertanyaannya adalah:

1. Dari skor 1-5, seberapa Anda merasa cemas/khawatir terhadap perkuliahan selama pandemi COVID-19 ini? (semakin besar angka yang Anda pilih, menunjukkan semakin cemas/ khawatir) Jelaskan mengapa Anda memilih angka tersebut!

2. Apa hal yang paling tidak Anda sukai dari pembelajaran jarak jauh selama pandemi COVID-19 ini? Mengapa? 
Data kemudian dianalisis dengan teknik analisis isi kualitatif. Prosedur analisis data meliputi: (1) mencatat seluruh respon yang masuk; (2) menentukan kata kunci tiap respon (satu responden dapat memiliki lebih dari satu respon dan kata kunci); (3) menetapkan tema dari setiap kata kunci yang ditemukan; dan (4) mengelompokkan tema-tema yang berdekatan ke dalam kategori-kategori. Melalui cara analisis itu, dapat ditemukan bentuk-bentuk tekanan psikologis responden dan faktor-faktor yang mempengaruhi. Dinamika tekanan psikologis yang dialami responden disusun berdasarkan logika sekuensial faktor-faktor yang mempengaruhi tekanan psikologis.

\section{Hasil dan Pembahasan}

Dari 548 responden, diperoleh sebanyak 778 respon. Sesuai pertanyaan dalam penelitian ini, hasil penelitian ini terdiri dari tiga bagian yaitu (1) deskripsi tekanan psikologis yang dialami mahasiswa saat belajar jarak jauh selama pandemi COVID19; (2) faktor-faktor yang mempengaruhi tekanan psikologis mahasiswa saat belajar jarak jauh selama pandemi COVID-19; dan (3) dinamika psikologis mahasiswa saat belajar jarak jauh selama pandemi COVID-19.

\section{Tekanan Psikologis yang Dialami Mahasiswa Saat Belajar Jarak Jauh Selama Pandemi COVID-19}

Hasil penelitian menunjukkan bahwa $89,3 \%$ responden menyatakan cemas atau mengalami tekanan psikologis akibat pandemi COVID-19 ini, dengan berbagai alasan. Dari seluruh responden, sebanyak $45,7 \%$ setiap hari mengikuti perkembangan informasi seputar COVID-19 dari berbagai media serta 50,6\% kadang-kadang mengikutinya. Hanya sebesar 3,7\% responden yang tidak mengikuti perkembangan informasi seputar COVID-19 setiap hari. Data ini kiranya berkorelasi dengan banyaknya responden yang menyatakan cemas. Hasil penelitian terdahulu menunjukkan bahwa semakin banyak seseorang mengikuti informasi tentang COVID-19, semakin meningkat pula tingkat kecemasannya (Riehm, Feder, Tormohlen, Crum, Young, Green, Pacek, Flair dan Mojtabai, 2019). Kondisi ini dipicu juga oleh model pembelajaran yang dilakukan secara jarak jauh. Tuntutan kerja yang dilakukan dalam jarak jauh secara online, terutama ketika masalah internet muncul dan jaringan lemah, merupakan stresor yang dapat beresiko munculnya depresi (Moawad, 2020).

Perubahan besar yang dialami mahasiswa selama pandemi COVID-19 ini adalah dari tingginya frekuensi beraktivitas di luar rumah menjadi harus tinggal di rumah atau di kos bagi mahasiswa yang berasal dari luar Yogyakarta, demi melakukan social distancing. Tekanan psikologis yang muncul selama PJJ dalam situasi ini adalah rasa cemas, panik, terbebani, bosan, kesepian, serta tidak percaya diri. Banyaknya mahasiswa yang mengalami tekanan psikologis dalam kondisi ini sesuai dengan hasil penelitian sebelumnya yang menemukan hubungan positif antara social distancing dengan kesehatan mental negatif (Marroquín, Vine dan Morgan, 2020).

Temuan penelitian ini menunjukkan bahwa bentuk-bentuk tekanan psikologis yang dialami mahasiswa selama pembelajaran jarak jauh dalam situasi pandemi ini dapat dikategorikan menjadi perasaan spontan yang muncul di awal-awal belajar jarak 
jauh, perasaan selama menjalani pembelajaran jarak jauh ketika pandemi belum juga berakhir, serta dampaknya terhadap keterlibatan dan motivasi belajar mahasiswa.

Perasaan cemas, panik dan terbebani menjadi reaksi pertama yang muncul saat beradaptasi dengan situasi belajar yang relatif baru di tengah pandemi. Ketika situasi pandemi dan proses perkuliahan yang dialami tidak kunjung membaik, mahasiswa merasa bosan dan kesepian, serta timbul rasa tidak percaya diri. Temuan ini mendukung temuan sebelumnya yang mengatakan bahwa pembelajar merasa terisolasi dan kesepian dalam lingkungan belajar online (Sit, Chung, Chow dan Wong, 2005; Zembylas, Theodorou dan Pavlakis, 2008). Akibat dari hal-hal tersebut adalah pada menurunnya motivasi untuk mengikuti pembelajaran. Rangkuman tekanan psikologis yang dialami responden dapat dilihat pada Gambar 1 .

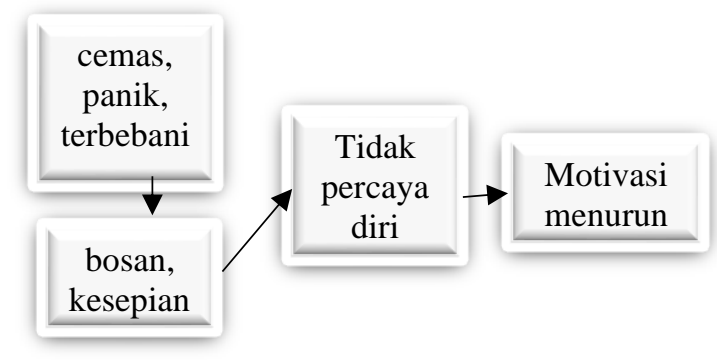

Gambar 1. Tekanan psikologis saat PJJ selama pandemic COVID-19 Sumber: Analisis penulis, 2020

Faktor-Faktor yang Mempengaruhi Kondisi Psikologis Mahasiswa Saat Belajar Jarak Jauh Selama Pandemi COVID-19

Dari 778 respon yang muncul, peneliti menemukan 10 kategori yang dianggap sebagai faktor-faktor yang mempengaruhi kondisi psikologis mahasiswa. Faktorfaktor tersebut adalah (1) faktor dari mahasiswa, yang meliputi kompetensi akademik dan softskill mahasiswa; (2) faktor dari dosen, yang mencakup kompetensi pengajaran dan penguasaan media pembelajaran serta etos kerja dosen; (3) lingkungan belajar; (4) kebutuhan bersosialisasi yang terhambat pemenuhannya akibat harus tinggal di rumah; (5) fasilitas belajar, yakni fasilitas untuk belajar jarak jauh serta dukungan finansial; (6) proses belajar, yang terdiri dari pengelolaan pembelajaran serta relasi dan komunikasi; serta (7) kondisi fisik mahasiswa.

Faktor input yang mempengaruhi tekanan psikologis mahasiswa saat PJJ terdiri dari mahasiswa dan dosen. Dari pihak mahasiswa, faktor yang berpengaruh adalah kompetensi akademik serta softskill. Dalam penelitian ini ditemukan ketidakmampuan mahasiswa dalam mengutarakan pendapatnya secara online, sulit memahami materi perkuliahan yang disampaikan dalam jaringan, serta kesulitan mengerjakan tugas-tugas yang diberikan.

Dari pihak dosen, kompetensi dalam pengajaran jarak jauh serta etos kerja merupakan faktor yang paling berpengaruh. Kompetensi tersebut secara lebih spesifik meliputi kekurangmampuan dosen dalam menguasai teknologi, 
ketidakmampuan menjelaskan materi dalam jaringan dan ketidakpedulian pada keadaan mahasiswa sehingga memberikan tugas atau organisasi materi kuliah yang tidak sesuai dengan kondisi mahasiswa. Jika dilihat dari semangatnya, pembelajaran jarak jauh memberikan fleksibilitas waktu dan tempat yang luas dan memungkinkan pembelajar melakukan pengaturan sendiri, sesuai kebutuhan belajar masing-masing. Dalam sistem ini, peran pengajar adalah sebagai mediator atau fasilitator. Artinya, pengajar harus memberikan bekal atau cara yang tepat bagi pembelajar untuk dapat mengkonstruksi belajar sendiri (Goulao, 2012 dalam Goulao, 2014). Menurut Azevedo dan Cromley (2004), implikasi dari rancangan lingkungan belajar virtual bagi capaian pembelajaran adalah perlunya pengajar sadar untuk memberikan kemampuan pembelajar dalam meregulasi belajar sendiri terlebih dahulu. Jika kemampuan ini tidak dimiliki, maka dapat menimbulkan tekanan psikologis.

Ketidaksiapan dosen dalam menjalankan pembelajaran jarak jauh dapat membuat mahasiswa kehilangan kemampuan mengatur diri, sehingga justru sulit mengatur waktu, sulit fokus, sulit belajar mandiri, serta menjadi tidak produktif. Hal-hal tersebut memicu munculnya tekanan psikologis.

Faktor lingkungan belajar yang berkontribusi bagi tekanan psikologis yang dialami mahasiswa adalah adanya distraksi dari lingkungan serta suasana belajar yang tidak kondusif. Sebagaimana diketahui, PJJ yang terjadi saat ini dapat dikatakan berlangsung secara instan, tanpa persiapan matang sebelumnya, baik dari dosen maupun mahasiswa. Ketika mahasiswa harus kembali ke rumah masing-masing atau ke kos, belum tentu memiliki tempat belajar yang memadai dengan fasilitas yang diperlukan untuk belajar.

Kebutuhan bersosialisasi yang tidak terpenuhi selama pandemi, juga menjadi faktor yang berpengaruh terhadap tekanan psikologis yang dialami mahasiswa. Kebutuhan bersosialisasi ini meliputi baik sosialisasi dalam konteks diskusi materi pembelajaran maupun di luar urusan akademik. Selain dengan teman, kebutuhan sosialisasi yang tidak terpenuhi adalah interaksi dengan dosen. Keharusan melakukan social distancing sangat membatasi interaksi di antara mahasiswa dan dosen. Selain itu, pembelajaran jarak jauh yang tidak disertai rancangan diskusi online yang baik serta dosen yang kurang responsif, tentu menimbulkan ketidakpuasan dalam pembelajaran, yang berpengaruh pada kesehatan mental mahasiswa. Hal ini sejalan dengan temuan Kuo, Walker, Belland dan Schroder (2013) yang menyebutkan bahwa dalam pembelajaran jarak jauh, interaksi merupakan hal yang sangat penting. Interaksi antara pengajar dengan pembelajar, sesama pembelajar dan interaksi pembelajar dengan konten belajar merupakan prediktor penting bagi kepuasan belajar.

Faktor yang berpengaruh pada tekanan psikologis lainnya adalah fasilitas. Hal utama yang diperlukan dalam pembelajaran jarak jauh tentunya adalah media. Penelitian ini menemukan bahwa salah satu faktor yang membuat mahasiswa mengalami tekanan psikologis adalah media belajar, baik itu media yang terbatas maupun yang beragam tapi tidak terintegrasi. Media yang rawan memboroskan kuota dan mensyaratkan jaringan internet yang prima membuat mahasiswa semakin terasa tertekan. Setiap media pembelajaran memiliki karakteristik tersendiri, yang 
berarti membutuhkan strategi kognitif tersendiri pula (Keskin dan Yurdugül, 2020). Dalam perkuliahan di mana media yang digunakan dosen tidak terintegrasi satu sama lain, maka selain membutuhkan peralatan yang memadai untuk menyimpan banyak aplikasi, mahasiswa juga dituntut menggunakan strategi kognitif yang berbeda-beda dalam waktu yang cepat. Situasi ini terbukti mendatangkan tekanan psikologis bagi para pembelajar.

Proses belajar dalam PJJ meliputi pengelolaan belajar serta relasi dan komunikasi dalam pembelajaran. Pengelolaan pembelajaran jarak jauh merupakan faktor yang paling banyak ditemukan variasinya. Pengelolaan yang berpengaruh langsung terhadap kondisi psikologis mahasiswa ini meliputi ketidakjelasan sistem administrasi pembelajaran, banyak dan beratnya tugas-tugas yang diberikan, jadwal/ sistem belajar yang tidak teratur, penjelasan materi yang kurang memadai, evaluasi pembelajaran yang tidak jelas, serta pelaksanaan mata kuliah berpraktek yang tertunda atau dilakukan dengan banyak keribetan.

\section{Dinamika Terjadinya Tekanan Psikologis Mahasiswa Saat Belajar Jarak Jauh Selama Pandemi COVID-19}

Ketidakjelasan sistem evaluasi dan berbagai hal terkait penilaian pembelajaran terbukti membuat mahasiswa mengalami kebingungan, yang berdampak pada ketidakyakinan mereka tentang capaian pembelajaran mereka sendiri. Keluhan mengenai banyaknya tugas yang berat dengan batas waktu pengumpulan yang sempit merupakan keluhan yang paling banyak muncul, apalagi tugas-tugas yang tak kunjung diberi feedback oleh para dosen.

Faktor yang berpengaruh langsung terhadap munculnya tekanan psikologis adalah kondisi tidak yakin terhadap kemampuan diri. Ketidakyakinan terhadap kemampuan diri ini biasa disebut efikasi diri. Menurut Peters, WcEwen dan Friston (2017), stres terjadi ketika seseorang merasa tidak yakin atau tidak jelas terhadap sesuatu yang penting, yang berpengaruh pada kesehatan fisik dan mental. Stresor paling kuat yang mempengaruhi mahasiswa dalam pembelajaran adalah ketidakyakinannya terhadap nilai yang diperoleh dan evaluasi pembelajarannya (Moawad, 2020).

Selain dipengaruhi oleh ketidakjelasan dalam evaluasi pembelajaran, ketidakyakinan mahasiswa terhadap capaian belajarnya juga muncul karena ketidakteraturan jadwal dan sistem belajar, tidak adanya penjelasan materi atau ada penjelasan tetapi kurang memadai, serta minimnya komunikasi dengan dosen maupun sesama mahasiswa. Kondisi ini berakibat pada rasa tidak percaya terhadap pengajar dan kegagalan melihat value penting dalam proses belajar. Kedua hal tersebut memainkan peran penting dalam keberhasilan pembelajaran jarak jauh sebagaimana ditemukan oleh Hughes dan Daykin (2002) yang menyebutkan pentingnya pembelajar dan pengajar melihat value yang ada dan percaya dengan berbagai platform yang digunakan. Jika pembelajar percaya pada pengajar dan media yang digunakan, maka pembelajar akan lebih mudah terlibat dalam pengalaman belajar yang dilakukan. Sebaliknya, kegagalan terjadi jika pengelola pembelajaran tidak dilatih menggunakan program online, desain yang digunakan tidak tepat, atau jika pengelolaan finansial tidak kuat (Rovai dan Downey, 2010). 
Pengelolaan pembelajaran yang tidak optimal ini dipengaruhi oleh tiga faktor, yakni faktor dosen, fasilitas, serta mahasiswa itu sendiri. Keterbatasan dosen dalam menguasai platform pembelajaran yang digunakan, rendahnya kompetensi belajar mandiri mahasiswa, serta ketidakstabilan jaringan internet merupakan paduan faktor yang berpengaruh langsung bagi tidak optimalnya penyampaian materi ajar, yang selanjutnya berdampak pada efikasi diri, penilaian tentang berharganya pembelajaran, serta motivasi untuk terlibat dalam belajar. Keskin dan Yurdugül (2020) menemukan adanya korelasi antara kecenderungan memilih model penyampaian bahan ajar, efikasi diri, motivasi, serta penilaian tentang berharganya suatu tugas.

Kondisi stres yang ada pada mahasiswa akan berdampak pada menurunnya motivasi belajar. Motivasi merupakan bagian penting dalam pembelajaran jarak jauh (Selim, 2007). Hasil penelitian terdahulu menunjukkan bahwa ada korelasi kuat antara motivasi dengan kesuksesan pelajar dan keterlibatan dalam pembelajaran online (Keskin dan Yurdugül, 2020). Berdasar temuan tentang menurunnya motivasi belajar mahasiswa dalam penelitian ini, serta dukungan hasil penelitian sebelumnya tersebut, maka kondisi psikologis mahasiswa yang menurunkan motivasi belajar dalam temuan penelitian ini perlu mendapat perhatian dengan mencari faktor-faktor yang mempengaruhinya. Kerangka kerja tekanan psikologis mahasiswa saat belajar jarak jauh selama pandemic COVID-19 dapat dilihat pada Gambar 2.

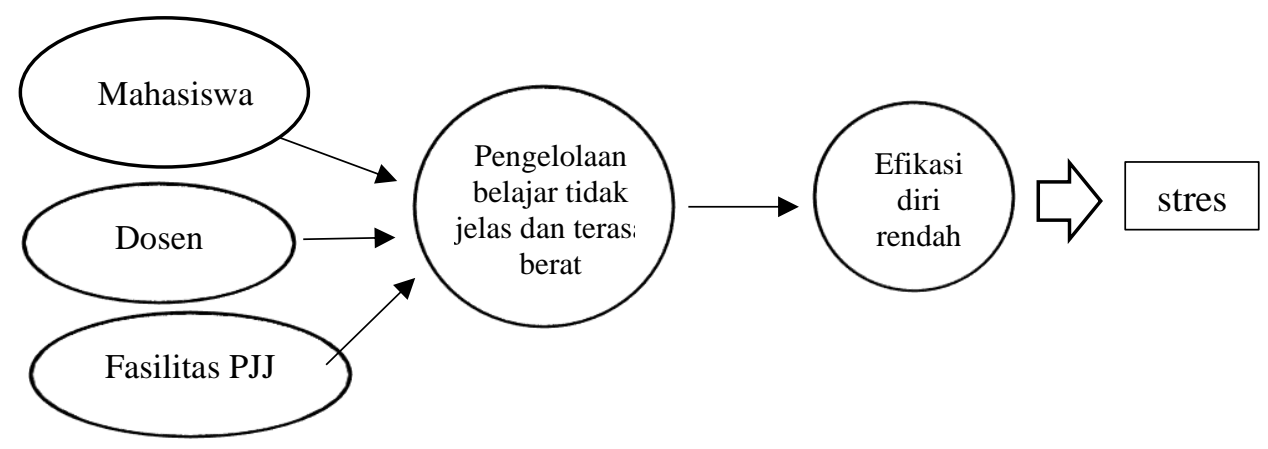

Gambar 2. Dinamika tekanan psikologis mahasiswa saat belajar jarak jauh selama pandemi COVID-19

Sumber: Analisis penulis, 2020

\section{Kesimpulan}

Hasil penelitian menemukan adanya tekanan psikologis yang dialami mahasiswa saat belajar jarak jauh selama pandemic COVID-19. Bentuk tekanan psikologis yang muncul adalah cemas, panik, terbebani, bosan, kesepian dan tidak percaya diri. Hal ini berdampak pada menurunnya motivasi belajar. Faktor yang mempengaruhi tekanan psikologis secara langsung adalah ketidakyakinan terhadap kemampuan sendiri yang terjadi karena ketidakjelasan pengelolaan belajar beserta evaluasinya. Ketidakjelasan tersebut muncul karena kombinasi faktor kompetensi dan etos kerja dosen, kompetensi akademik dan softskill mahasiswa, serta kurang memadainya fasilitas pembelajaran jarak jauh. 
Berdasar temuan dalam penelitian ini, memikirkan bagaimana membuat struktur yang lebih jelas, penuh persiapan dan pertimbangan komprehensif, kiranya menjadi kesempatan baik yang dapat dilakukan untuk menyiapkan perkuliahan jarak jauh, baik yang bersifat darurat menanggapi situasi pandemi maupun yang dapat dipikirkan sebagai sajian perkuliahan dalam jangka panjang ke depan.

\section{Ucapan Terima Kasih}

Ucapan terima kasih penulis ucapkan kepada para mahasiswa peserta kuliah Metodologi Penelitian Kuantitatif Fakultas Psikologi Universitas Sanata Dharma kelas B Semester Genap 2019/2020 yang telah membantu dalam proses mengumpulkan data penelitian.

\section{Daftar Pustaka}

Aparicio, M., Bacao, F., Oliveira, T. (2016). An e-learning theoretical framework. An E-Learning Theoretical Framework Educational Technology \& Society, 19(1), 292-307.

Azevedo, R. dan Cromley, J.G., (2004). Does training on self -regulated learning facilitate student's learning with hypermedia? Journal of Educational Psychology, 96, (3), 523-535.

Bjork, R.A., Dunlosky, J., Kornell, N. (2013). Self-regulated learning: Beliefs, techniques, and illusions. Annual Review of Psychology, 64, 417-444.

Bušelić, M. (2012). Distance Learning-concepts and contributions. Oeconomica Jadertina, 2(1), 23-34.

Dwyer, A.L. dan Cummings, A.L. (2001). Stress, self-efficacy, social support, and coping strategies in university students. Canadian Journal of Counselling and Psychotherapy, 35(3), 208-220

Ellis, R.A., Jarkey, N., Mahony, M.J., Peat, M., Sheely, S. (2007). Managing quality improvement of e learning in a large, campus-based university. Quality Assurance in Education, 15(1), 9-23.

Goulao, M.F. (2014). The relationship between self-efficacy and academic achievement in adults' learners. Athens Journal of Education, 1(3),237-246.

Hughes, M. dan Daykin, N. (2002). Towards constructivism: Investigating students' perceptions and learning as a result of using an online environment. Innovations in Education and Teaching International, 39(3), 217-224.

Keskin, S. dan Yurdugül, H. (2020). Factors affecting students' preferences for online and blended learning: Motivational vs. cognitive. European Journal of Open, Distance and E-Learning, 22(2), 72-86.

Kuo, Y.C., Walker, A.E., Belland, B.R. dan Schroder, K.E. (2013). A predictive study of student satisfaction in online education programs. International Review of Research in Open and Distributed Learning, 14(1), 16-39.

Lazarus, R.S. dan Folkman, S. (1984). Stress, appraisal, and coping. Springer publishing company.

Lo, C.C. (2010). How student satisfaction factors affect perceived learning. Journal of the Scholarship of Teaching and Learning, 10(1), 47-54. 
Macejka, M. (2014). The role of grade level and locus of control in self-regulated learning strategies of college students. Journal of Education, Psychology and Social Sciences, 1(2), 1339-1488.

Marroquín, B., Vine, V. dan Morgan, R. (2020). Mental health during the COVID19 pandemic: Effects of stay-at-home policies, social distancing behavior, and social resources. Psychiatry Research, 293, 113419.

Moawad, R.A. (2020). Online Learning during the COVID-19 pandemic and academic stress in university students. Revista Românească pentru Educaţie Multidimensională, 12(1 Sup2), 100-107.

Pascoe, M.C., Hetrick, S.E. dan Parker, A.G. (2020). The impact of stress on students in secondary school and higher education. International Journal of Adolescence and Youth, 25(1), 104-112.

Peters, A., McEwen, B.S. dan Friston, K. (2017). Uncertainty and stress: Why it causes diseases and how it is mastered by the brain. Progress in Neurobiology, 156, 164-188.

Ribeiro, Í.J.S., Pereira, R., Freire, I.V., Oliveira, B.G.D., Casotti, C.A. dan Boery, E.N. (2017). Stress and quality of life among university students: A systematic literature review. Health Professions Education, 4, 70-77.

Riehm, K.E., Feder, K.A., Tormohlen, K.N., Crum, R.M., Young, A.S., Green, K.M., Pacek, L.R., Flair, L.N.L. dan Mojtabai, R. (2019). Associations between time spent using social media and internalizing and externalizing problems among US youth. JAMA Psychiatry, 76(12), 1266-1273.

Rovai, A.P. dan Downey, J.R. (2010). Why some distance education programs fail while others succeed in a global environment. The Internet and Higher Education, 13(3), 141-147.

Selim, H.M. (2007). Critical success factors for e-learning acceptance: Confirmatory factor models. Computers dan Education, 49(2), 396-413

Sit, J.W., Chung, J.W., Chow, M.C. dan Wong, T.K. (2005). Experiences of online learning: students' perspective. Nurse Education Today, 25(2), 140-147.

Zembylas, M., Theodorou, M., Pavlakis, A. (2008). The role of emotions in the experience of online learning: Challenges and opportunities. Educational Media International, 45(2), 107-117. 